\title{
Corrosion properties of the superelastic shape memory Ni-Ti alloy for medical implants
}

Dalibor Vojtěch, Jiří Kubásek, Pavel Novák

Department of Metals and Corrosion Engineering, Institute of Chemical Technology, Prague, Technická 5, 16628 Prague 6, Czech Republic. Dalibor.Vojtech@vscht.cz

The Ni-Ti alloy (Nitinol, approx. 50 at. \% Ni) is a biomaterial showing the shape memory and superelasticity effects. These characteristics make this material of interest for biomedical applications, especially for manufacture of stents, i.e., tubular implants for restoring damaged blood vessels, oesophageus etc. The corrosion resistance in the human body environment is a very important factor determining the life time of implants. An insufficient corrosion resistence may lead to fractures of implants, formation of dangerous fragments and to serious health problems for patients. The corrosion behavior is influenced mainly by the surface structure and chemistry of a material. But the surface state is strongly modified by chemical and heat treatment processes used in the implant manufacture. Therefore, in this study the relationships between chemical treatment and heat treatment regimes, surface state of Nitinol and its corrosion resistance in simulated physiological solution are demonstrated. It is shown that, unlike chemical pre-treatment, heat treatment used in the manufacture of stents generally negatively influences the corrosion resistance. The findings are discussed in relation to the surface state and chemistry of the material.

Keywords: Ni-Ti alloy, Nitinol, corrosion, structure, surface, heat treatment

Acknowledgements

Research on Ni-Ti alloys is financially supported by the Czech Science Foundation (project no. P108/12/G043).

\section{References}

[1] DAVIS, J.R. (1990). ASM Handbook, Volume 2, Properties and Selection: Nonferrous Alloys and SpecialPurpose Materials, ASM International, Materials Park.

[2] DAVIS, J.R. (2003). Handbook of materials for medical devices. ASM International, Materials Park.

[3] KHALIL-ALLAFI, J., DLOUHÝ, A., EGGELER, G. (2002). $\mathrm{Ni}_{4} \mathrm{Ti}_{3}$-precipitation during aging of NiTi shape memory alloys and its influence on martensitic phase transformations. Acta Materialia, 50, 17, pp. 4255-4274.

[4] BORN, P. (2009). Multiple breakage of a covered esophageal stent. Endoscopy, 41, pp. 34.

[5] GOENKA, A.H., GARG, P. K., SHARMA, R., SHARMA, B. (2009). Spontaneous fracture of an uncovered enteral stent with proximal migration of fractured segment into cervical esophagus: first report. Endoscopy, 41, pp. 204-205.

[6] WIEDMANN, M., HELLER, F., ZEITZ, M., MOSSNER, J. (2009). Fracture of a covered self-expanding antireflux stent in two patients with distal esophageal carcinoma. Endoscopy, 41, pp. 129-130.

[7] ZHU, L., FINO, J.M., PELTON, A., DUERIG, T. (2004). Proceedings of the International Conference on Shape Memory and Superelastic Technologies, SMST. ASM International, Materials Park.

[8] KIM, J.I., MIYAZAKI, S. (2005). Effect of nano-scaled precipitates on shape memory behavior of Ti-50.9 at. \% Ni alloy. Acta Materialia, 53, 17, pp. 4545-4554.

[9] MIYAZAKI, S., OTSUKA, K. (1986). Deformation and transition behavior associated with the R-phase in Ti-Ni alloys. Metallurgical Transactions, 17A, 1, pp. 53-63.

[10] ZHOU, Y., ZHANG, J., FAN, G., DING, X., SUN, J., REN, X., OTSUKA, K. (2005). Origin of 2-stage R-phase transformation in low-temperature aged Ni-rich Ti-Ni alloys. Acta Materialia, 53, 20, pp. 5365-5377.

[11] FRICK, C.P., ORTEGA, A.M., TYBER, J., MAKSOUND, A.E.M., MAIER, H.J., LIU, Y., GALL, K. (2005). Thermal processing of polycrystalline NiTi shape memory alloys. Materials Science and Engineering, A405, 1-2, pp. 34-49.

[12] PELTONEN, M., LiNDROOS, T., KALLIO, M. (2008). Effect of ageing on transformation kinetics and internal friction of Ni-rich Ni-Ti alloys. Journal of Alloys and Compounds, 460, 1-2, pp. 237-245.

[13] CHROBAK, D., STROZ, D. (2005). Two-stage R phase transformation in a cold-rolled and annealed Ti-50.6 at.\%Ni alloy. Scripta Materialia, 52, 8, pp. 757-760.

[14] ZHOU, Y., FAN, G., ZHANG, J., DING, X., REN, X., SUN, J., OTSUKA, K. (2006). Understanding of multistage R-phase transformation in aged Ni-rich Ti-Ni shape memory alloys, Materials Science and Engineering, A438-440, pp. 602-607.

[15] KIM, J.I., LIU, Y., MIYAZAKI, S. (2004). Ageing-induced two-stage R-phase transformation in Ti-50.9 at.\% Ni, Acta Materialia, 52, 2, pp. 487-499.

[16] FILIP, P., MAZANEC, K. (2001). On precipitation kinetics in TiNi shape memory alloys. Scripta Materialia, 45, 
6, pp. 701-707.

[17] JONES, D.A. (1996). Principles and Prevention of Corrosion. Prentice Hall, Upper Saddle River.

[18] HURTALOVÁ, L., TILLOVÁ, E. (2013). Elimination of the negative effect of Fe-rich intermetallic phases in secondary (recycled) aluminium část alloy In: Manufacturing Technology, No. 1, Vol. 13, pp. 44-50.

[19] POKOVÁ, M., CIESLAR, M., LACAZE, J. (2012). TEM Investigation of Precipitation in Al-Mn Alloys with Addition of Zr. In: Manufacturing Technology, No. 13, Vol. 12, pp. 212217.

[20] MICHALCOVÁ, A., VOJTĚCH, D. (2012). Structure of rapidly solidified aluminium alloys In: Manufacturing Technology, No.13, Vol. 12, pp.166-169. 